\title{
SUMMER 1986
}

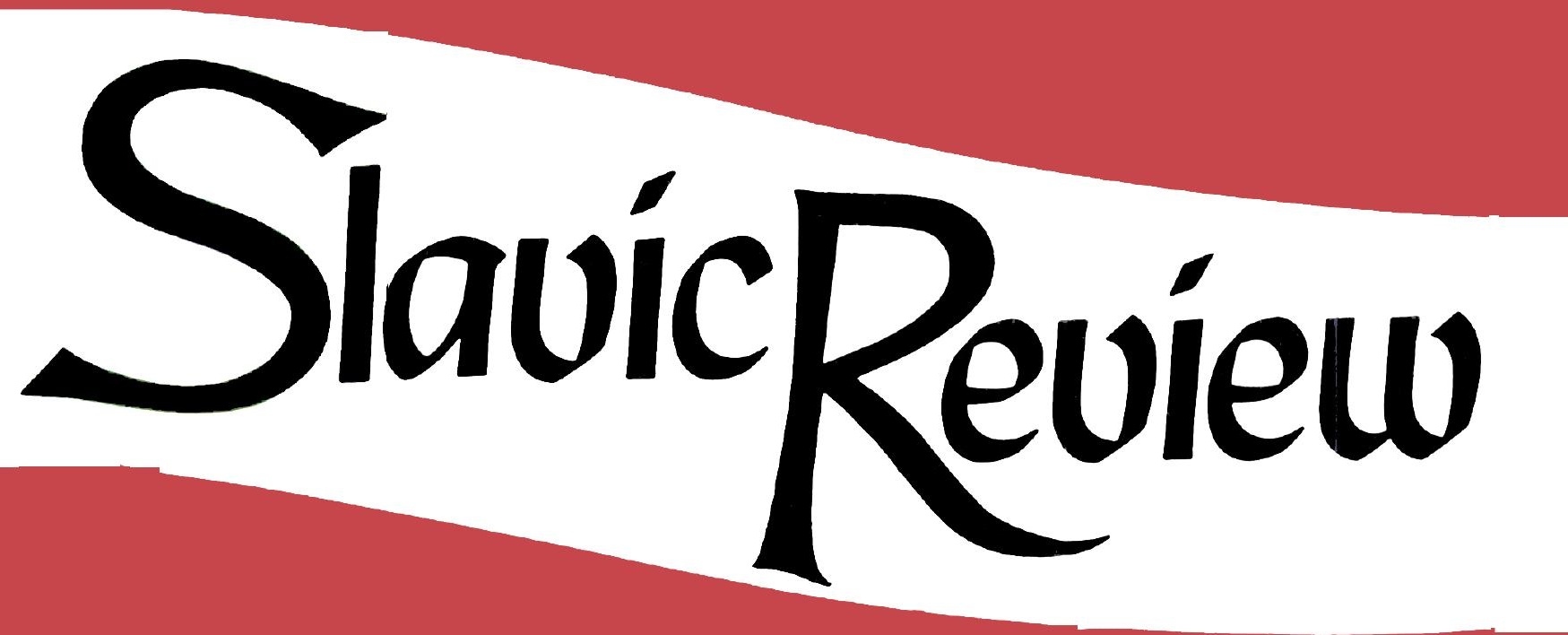

\section{AMERICAN QUARTERLY OF SOVIET AND EAST EUROPEAN STUDIES}

\section{DISCUSSION}

Robert W. Thurston : Fear and Belief in the USSR's “Great Terror":

Response to Arrest, 1935-1939

Comment by Robert Conquest

ARTICLES

Olga Peters Hasty : Tsvetaeva's Onomastic Verse

Barbara Alpern Engel : The Woman's Side: Male Out-Migration and the Family Economy in Kostroma Province

Carol Avins : Reaching a Reader: The Master's Audience in The Master and Margarita

NOTES AND COMMENTS

Robert Lewis : Science, Nonscience, and the Cultural Revolution 


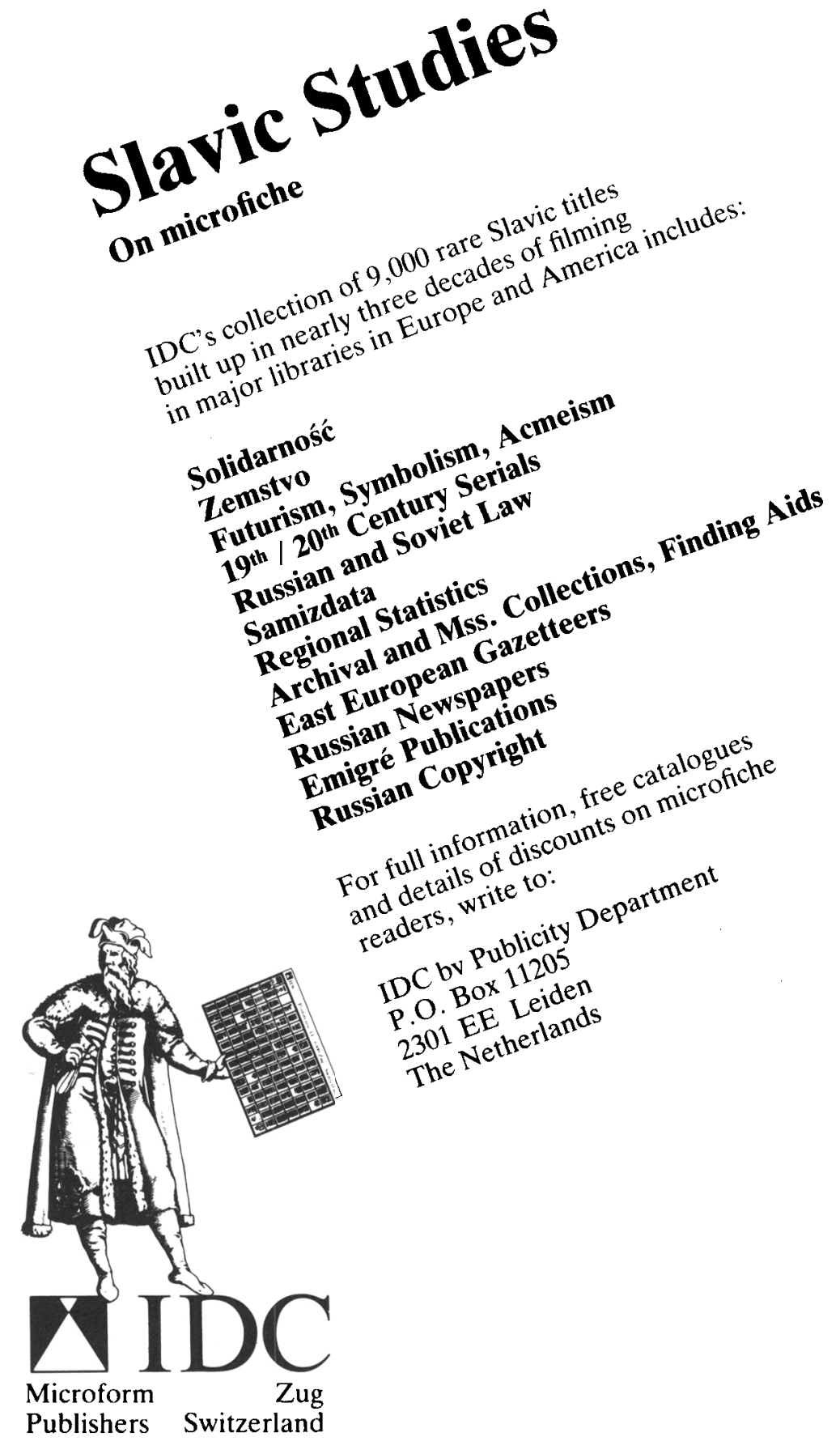




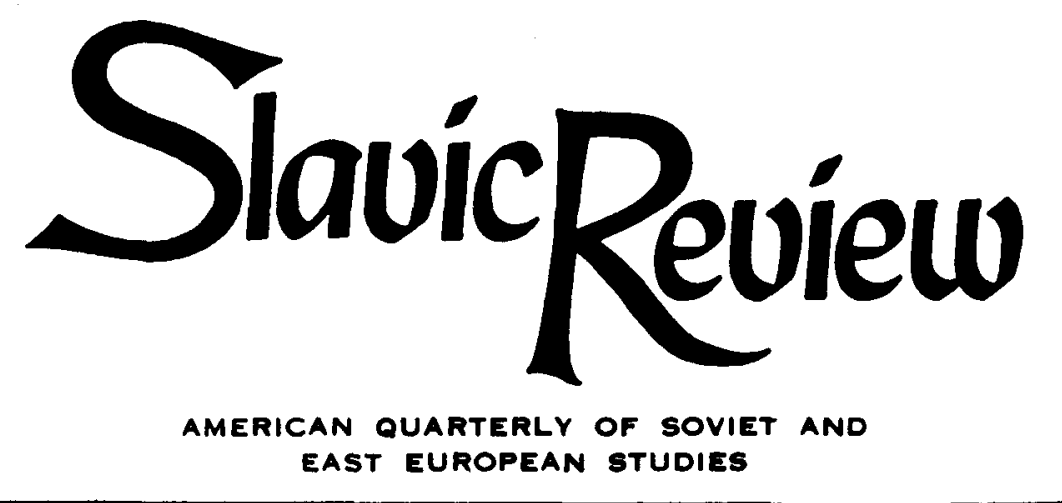

VOLUME 45 NUMBER 2 • SUMMER 1986

\section{DISCUSSION}

Fear and Belief in the USSR's "Great Terror":

Response to Arrest, 1935-1939

ROBERT W. THURSTON

What is Terror?

ROBERT CONQUEST

On Desk-Bound Parochialism, Commonsense

Perspectives, and Lousy Evidence: A Reply to

Robert Conquest

ROBERT W. THURSTON

\section{ARTICLES}

Tsvetaeva's Onomastic Verse

, OLGA PETERS HASTY

The Woman's Side: Male Out-Migration and the

Family Economy in Kostroma Province

BARBARA ALPERN ENGEL

Reaching a Reader: The Master's Audience in The Master and Margarita

CAROL AVINS

\section{NOTES AND COMMENTS}

Science, Nonscience, and the Cultural Revolution ROBERT LEWIS 


\section{REVIEWS}

Charles J. Halperin, Russia and the Golden Horde: The Mongol Impact on Medieval Russian History (Robert $\mathrm{O}$. Crummey)

Sigurd O. Shmidt, Rossiiskoe gosudarstvo v seredine XVI stoletiia. Tsarskii arkhiv $i$ litsevye letopisi vremeni Ivana Groznogo (Daniel Clark Waugh)

Nickolas Lupinin, Religious Revolt in the XVIIth Century: The Schism of the Russian Church (David Scheffel)

V. T. Pashuto, ed., Drevneishie gosudarstva na territorii SSSR: Materialy $i$ issledovaniia, 1983 god (Daniel H. Kaiser)

George Gajecky and Alexander Baran, The Cossacks in the Thirty Years War, Volume 1: 1619-1624; Volume 2: 16251648 (Alexander Sydorenko)

Aleksandr Il'ich Kopanev, Krest'iane russkogo severa $v$ XVII v (Brian Davies)

Erik Tiberg, Zur Vorgeschichte des livländischen Krieges: Die Beziehungen zwischen Moskau und Litauen, 1549-1562 (Hugh F. Graham)

Gary Marker, Publishing, Printing, and the Origins of Intellectual Life in Russia, 1700-1800 (Gregory L. Freeze)

Erich Donnert, Russland im Zeitalter der Aufklärung (Max J. Okenfuss)

Erich Donnert, Neue Wege im russischen Geschichtsdenken des 18. Jahrhunderts (Edward C. Thaden)

Maia Dmitrievna Kurmacheva, Krepostnaia intelligentsiia Rossii (vtoraia polovina XVIII nachalo XIX veka) (Walter Gleason)

Cynthia H. Whittaker, The Origins of Modern Russian Education: An Intellectual Biography of Count Sergei Uvarov, 1786-1855 (Alexander Vucinich)

Marianna Tax Choldin, A Fence around the Empire: Russian Censorship of Western Ideas under the Tsars (Daniel Balmuth)

Gregory L. Freeze, The Parish Clergy in Nineteenth-Century Russia: Crisis, Reform, Counter-Reform (Terence Emmons)

G. A. Tishkin, Zhenskii vopros v Rossii 50-60 gg. XIV v. (Barbara Alpern Engel)

Stephen M. Berk, Year of Crisis, Year of Hope: Russian Jewry and the Pogroms of 1881-1882 (Steven J. Zipperstein)

George Tokmakoff, P. A. Stolypin and the Third Duma: An Appraisal of the Three Major Issues (Robert Edelman)

Hans Björkegren, Ryska posten: De ryska revolutionärerna i norden 1906-1917 (Margareta O. Thompson)

Carl Andreas Koefoed, My Share in the Stolypin Reforms (David A. J. Macey) 
Roman Buhler et al., Schweizer im Zarenreich. Zur Geschichte der Auswanderung nach Russland; Urs Rauber, Schweizer Industrie in Russland. Ein Beitrag zur Geschichte der industriellen Emigration, des Kapitalexportes und des Handels der Schweiz mit dem Zarenreich (1760-1917) (Alfred Erich Senn)

Alex De Jonge, The Life and Time of Grigorii Rasputin; V. M. Purishkevich, The Murder of Rasputin (Mark Kulikowski)

Robert M. Cutler, trans. and ed., Mikhail Bakunin-From Out of the Dustbin: Bakunin's Basic Writings, 1869-1871 (Paul Avrich)

Robert Service, Lenin: A Political Life: Volume 1: The Strength of Contradiction (Itzhak Brudny)

A. Zimin, $U$ istokov stalinizma, 1918-1923 (Stephen Blank)

Paul B. Anderson, No East or West (Marc Raeff)

Ronald J. Hill, The Soviet Union: Politics, Economics, and Society: From Lenin to Gorbachev (Joel C. Moses)

Vitaly Rapoport and Yuri Alexeev, High Treason: Essays on the History of the Red Army, 1918-1938 (Mark von Hagen)

J. Arch Getty, Origins of the Great Purges: The Soviet Communist Party Reconsidered, 1933-1938 (Lewis H. Siegelbaum)

Vladimir Lavrinenkov, Bez voiny (Matthew Evangelista)

Alexander Yanov, The Drama of the Soviet 1960s: A Lost Reform (Roy D. Laird)

Hans-Joachim Torke, ed., Lexikon der Geschichte Russlands:

Von den Anfängen bis zur Oktober-Revolution (Gregory L. Freeze)

Robbin F. Laird, France, the Soviet Union, and the Nuclear Weapons Issue (Bradley R. Gitz)

P. Edward Haley, David M. Keithly, and Jack Merritt, eds., Nuclear Strategy, Arms Control, and the Future (Philip S. Gillette)

Steven J. Brams, Superpower Games: Applying Game Theory to Superpower Conflict (Richard J. Stoll)

Vladimir Nikolayev, The Americans (Elizabeth Schillinger)

Neil Malcolm, Soviet Political Scientists and American Politics (Carol R. Saivetz)

Joachim Krause, Die sowjetische Militärhilfepolitik gegenüber Entwicklungsländern (Roger E. Kanet)

Carol R. Saivetz and Sylvia Woodby, Soviet-Third World Relations (Daniel S. Papp)

Jessica Brown et al., comps., Sino-Soviet Conflict: $A$ Historical Bibliography; Gilbert Rozman, A Mirror for Socialism: Soviet Criticisms of China; Tsui Tsien-hua, The SinoSoviet Border Dispute in the 1970s (Donald W. Treadgold) 
Arthur J. Klinghoffer with Judith Apter, Israel and the Soviet Union: Alienation or Reconciliation? (Robert O.

Freedman)

Christopher Coker, Nato, the Warsaw Pact and Africa (Elizabeth Kridl Valkenier)

Ronald Tiersky, Ordinary Stalinism: Democratic Centralism and the Question of Communist Political Development (Robert D. English)

Robert Bideleux, Communism and Development (Elizabeth Kridl Valkenier)

Joan DeBardeleben, The Environment and Marxism-Leninism:

The Soviet and East German Experience (Charles E. Ziegler)

Archie Brown, ed., Political Culture and Communist Studies; Helmut Sonnenfeldt, ed., Soviet Politics in the 1980s (Peter Rutland)

Kenneth M. Currie and Gregory Varhall, eds., The Soviet Union: What Lies Ahead? Military-Political Affairs in the 1980s (Raymond L. Garthoff)

James M. Swanson, Scientific Discoveries and Soviet Law: A Sociohistorical Analysis (John A. Martens)

Timothy W. Luke, Ideology and Soviet Industrialization (Thomas F. Remington)

George Martin Weinberger, comp. and ed., Soviet Cybernetic Technology: A Timeline, Researcher's Data Base, and Guide to Professional Literature from Early First Generation through Third Generation, Volumes 1 and 2 (Ross A. Stapleton)

Raymond Hutchings, The Structural Origins of Soviet Industrial Expansion (Judith Thornton)

Michal Mirski, The Mixed Economy NEP and Its Lot (Hiroaki Kuromiya)

Barbara Holland, ed., Soviet Sisterhood (Richard Stites)

Helene Celmina, Women in Soviet Prisons (Barbara E. Clements)

Dimitry Pospielovsky, The Russian Church under the Soviet Regime, Volumes 1 and 2 (William C. Fletcher)

Benjamin Pinkus, The Soviet Government and the Jews, 19481967: A Documented Study (John D. Klier)

Roland Sussex and J. C. Eade, eds., Culture and Nationalism in Nineteenth-Century Eastern Europe (Geoff Eley)

Adam Bromke, Eastern Europe in the Aftermath of Solidarity (Jan T. Gross)

Antoni Mączak, Henryk Samsonowicz, and Peter Burke, eds., East Central Europe in Transition: From the Fourteenth to the Seventeenth Century (Frank E. Sysyn) 
Jadwiga Staniszkis, Poland's Self-Limiting Revolution; Jan B. de Weydenthal, Bruce D. Porter, and Kevin Devlin, The Polish Drama 1980-1982 (Andrzej Korbonski)

Bruno Shatyn, A Private War: Surviving in Poland on False Papers, 1941-1945 (Valerie Z. Nollan)

Zygmunt Dulczewski, Florian Znaniecki: Życie i dzieto (Aleksander Gella)

Janina Leskiewicz and Franciszka Ramotowska, eds., Obraz

Królestwa Polskiego w okresie konstytucyjnym. Tom 1: Raporty Rady Stanu Królestwa Polskiego z działalności rzqdu $w$ latach 1816-1828 (Adam A. Hetnal)

Bogna Lorence-Kot, Child-Rearing and Reform: A Study of the Nobility in Eighteenth-Century Poland (Daniel Stone)

Hartmut Zimmerman with Horst Ulrich and Michael Fehlaurer, eds., DDR-Handbuch. Band 1: A-L; Band 2: $M-Z$ (Melvin Croan)

Henry Krisch, The German Democratic Republic: The Search for Identity (Norman M. Naimark)

Phillip J. Bryșon, The Consumer under Socialist Planning: The East German Case (Bogdan Mieczkowski)

Federální statistický úřad, comp., Historická statistická ročenka ČSSR (Zdenek Salzmann)

Béla Borsi-Kalman, Együtt Vagy Külön Utakon: A Kossuth-Emigráció és a Román Nemzeti Mozgalom Kapcsolatának Történetéhez (James P. Niessen)

Nigel Swain, Collective Farms which Work? (Ivan Szelenyi)

Fred Singleton, $A$ Short History of the Yugoslav Peoples (David MacKenzie)

George Christos Soulis, The Serbs and Byzantium during the Reign of Tsar Dušan (1331-1355) and His Successors (George P. Majeska)

David MacKenzie, Ilija Garašanin: Balkan Bismark (Dimitrije Djordjevic)

Vasilije Dj. Krestic, Srpsko-Hrvatski odnosi i jugoslovenska ideja, 1860-1873 (David MacKenzie)

Pedro Ramet, Nationalism and Federalism in Yugoslavia, 19631983 (Ellen Comisso)

Nora Beloff, Tito's Flawed Legacy: Yugoslavia and the West since 1939 (Alex N. Dragnich)

Pedro Ramet, ed., Yugoslavia in the 1980s (Bogdan Denitch)

Michael Shafir, Romania: Politics, Economics, and Society (Keith Hitchins)

John W. Cole, Economy, Society, and Culture in Contemporary Romania (Mary Ellen Fisher)

Hannah Pakula, The Last Romantic: A Biography of Queen Marie of Roumania (Glenn E. Torrey) 
Alex N. Dragnich and Slavko Todorovich, The Saga of Kosovo: Focus on Serbian-Albanian Relations (Peter R. Prifti)

Theofanis G. Stavrou, ed., Modern Greek Studies Yearbook (Gareth Morgan)

Helena Sheehan, Marxism and the Philosophy of Science: A Critical History. Volume 1: The First Hundred Years (James P. Scanlan)

Martin Jay, Marxism and Totality: The Adventures of a Concept from Lukács to Habermas (Zoltán Tarr)

James P. Scanlan, Marxism in the USSR: A Critical Survey of Current Soviet Thought (Philip T. Grier)

Vladimir Propp, Theory and History of Folklore (Stephen P. Dunn)

Richard N. Coe, Reminiscences of Childhood: An Approach to a Comparative Mythology (Elizabeth Klosty Beaujour)

Samuel H. Baron and Carl Pletsch, eds., Introspection in Biography: The Biographer's Quest for Self-Awareness (Harlow Robinson)

Roger Cockrell and David Richards, eds., The Voice of a Giant: Essays on Seven Russian Prose Classics (Temira Pachmuss)

Lev Loseff, On the Beneficence of Censorship: Aesopian Language in Modern Russian Literature (Maurice Friedberg)

Leslie O'Bell, Pushkin's Egyptian Nights: The Biography of a Work (Ralph E. Matlaw)

Sarah Pratt, Russian Metaphysical Romanticism: The Poetry of Tiutchev and Boratynskii (Tomas Venclova)

N. N. Schneidman, Dostoevsky and Suicide; Louis Allain, Dostoïevski at l'autre (Nicholas O. Warner)

Boris Eikhenbaum, Tolstoi in the Sixties; Boris Eikenbaum, Tolstoi in the Seventies; B. M. Eikenbaum and Yuri Tynyanov, eds., Russian Prose (Carol Any)

Gustave Aucouturier, trans. and ed., Léon Tolstoi, Journaux et Carnets; R. F. Christian, ed. and trans., Tolstoy's Diaries, Volume 1: 1847-1894, Volume 2: 1895-1910 (Louise Smoluchowski)

Edgar H. Lehrman, A Handbook to Eighty-Six of Chekhov's Stories in Russian (Andrew R. Durkin)

Bernhard Lauer and Ulrich Steltner, eds., Fedor Sologub, 1884 1984: Texte, Aufsätze, Bibliographie (Stanley J. Rabinowitz)

Leonore Scheffler, Evgenij Samjatin: Sein Weltbild und seine literarische Thematik (Herman Ermolaev)

Brian Boyd, Nabokov's Ada: The Place of Consciousness (W. W. Rowe) 
John B. Dunlop, Richard S. Haugh, and Michael Nicholson, Solzhenitsyn in Exile: Critical Essays and Documentary Materials (Francis B. Randall)

Gerald Janecek, The Look of Russian Literature: Avant-Garde Visual Experiments, 1900-1930 (Juliette R. Stapanian)

Carl R. Proffer and Ellendea Proffer, eds., The Barsukov Triangle, the Two-Toned Blond, and Other Stories (Priscilla Meyer)

Roger Hagglund, The Vision of Unity: Adamovich in Exile; Roger Hagglund, comp., Georgy Adamovich: An Annotated Bibliography-Criticism, Poetry, and Prose, 19151980 (David M. Bethea)

Jovan Deretić, Srpski Roman 1800-1850 (Thomas Butler)

Helena Goscilo, trans. and ed., Russian and Polish Women's Fiction (Halina Stephan)

Ivan Klíma, My Merry Mornings (Stories from Prague) (F. W. Galan)

Peter J. Mayo, The Morphology of Aspect in Seventeenth-Century Russian (Based on Texts of the Smutnoe vremja) (Emily Klenin)

Michael S. Flier and Richard D. Brecht, eds., Issues in Russian Morphosyntax (Gilbert C. Rappaport)

Lászlo Hadrovics, Ungarische Elemente im Serbokroatischen (Gyula Décsy)

Laurence Senelick, Gordon Craig's Moscow Hamlet: A Reconstruction (Mesrop Kesdekian)

Peter Hames, The Czechoslovak New Wave; Daniel J. Goulding, Liberated Cinema: The Yugoslav Experience (F. W. Galan)

Denise Y. Youngblood, Soviet Cinema in the Silent Era (Nikita M. Lary)

Malcolm Hamrick Brown, ed., Russian and Soviet Music: Essays for Boris Schwarz (Robert W. Oldani)

Nicoletta Misler and John E. Bowlt, eds. and trans., Pavel Filonov: A Hero and His Fate, Collected Writings on Art and Revolution, 1914-1940 (Robin Milner-Gulland)

Robert Mdivani, Viktor Pliushchev, and Vadim Milshtein, with Viktor Teeter, comps., A Scholar's Guide to Humanities and Social Sciences in the Soviet Union: The Academy of Sciences of the USSR and the Academies of Sciences of the Union Republics (Patricia K. Grimsted) 
BOOKS RECEIVED

SYMPOSIA 